\title{
Investigation of Pre-service Teachers' Levels of Readiness to Technology Integration in Education
}

\author{
Cem Cuhadar \\ Trakya University, Turkey
}

\begin{abstract}
This study aims to expose the training and experience that pre-service teachers acquire in the course of their study at schools of education in regard to the use of information and communication technology (ICT). The study adopts the survey model and its sampling is comprised of 832 pre-service teachers who attend four different faculty of education in Turkey. The data were collected by means of a scale developed by Tondeur, van Braak, Siddiq and Scherer (2016) on the basis of SQD (Synthesis of Qualitative Evidence) model. It was basically found that pre-service teachers do not receive adequate training and support in regard to the use of ICT in education during the courses of their study at faculty of educations. This situation varies statistically according to gender and the faculty of education variables. In the process of technology integration in teacher education, it is important in terms of effectiveness and efficiency that resources other than human and human power are handled in a more realistic way. So, it is considered that the findings of the present study may help in the processes of planning and implementing the technology integration in teacher education.
\end{abstract}

Keywords: Technology integration; Teacher education; Preservice teachers; Teacher candidates

\section{Introduction}

Various studies suggest that in such a long termed and costly process as ICT integration in education, it is necessary to use the human and non-human resources efficiently and to maintain a holistic analysis for successful attempts of integration (Demiraslan \& Usluel, 2008; Goktas, Yildirim \& Yildirim, 2009; Kabakci-Yurdakul, 2011; Koehler \& Mishra, 2009; Sleegers, van den Berg \& Geijsel, 2000; TEDMEM, 2015). The fact that, despite all scientific findings, the problems regarding technological applications in education still continue, may be considered to signify that the core of the subject has not been handled yet. Although there are many vital components of successful technology integration in education, perhaps the most important of them, as well as the least emphasized one, is the process of teacher education. Jamieson-Proctor, Finger and Albion (2010) argue that the quality of the teacher is a critical factor that affects the success on the part of students. Teo (2015) asserts that teachers play a key role in successful technology integration for teaching and learning. No matter how much convenient the components of integration might be, from the technological infrastructure to the legal and administrative issues, the implementer are teachers and success is directly proportionate to his/her relevant capacity and performance. As a typical example, it is obvious that quality teacher education primarily underlies the successful 
educational system of Finland, which has received attention all around the world due to the results of PISA exams since 2000's (Sahlberg, 2010). Demirli (2013) contends that, despite the high level of investments in ICT, the level of effective use is quite low. Likewise, in a report published by OECD (2015), it is argued that, despite the common use of ICT around the world, there is no sound evidence for its positive impact on students' academic achievement, e.g. their scores in mathematics and reading. One of the basic reasons of this situation is that the teaching and learning process is focused not on pedagogic context but on the successive novelties in ICT integration. Besides, in technology integration attempts at schools, ICT is mostly used to facilitate the existing teaching methods instead of implementing a multi-faceted point of view in which different components are employed (TEDMEM, 2015; Teo, Chai, Hung, \& Lee, 2008). In other words, while a ICT-based transformation in learning is expected, the traditional teaching is maintained with the help of ICT. On the other hand, instead of generalize each ICT applications in schools, it should also be taken into account that more effective outcomes may be achieved by realistically planned applications of integration components such as technical infrastructure, in-service teacher training, leadership and vision.

In the information age, teacher education may not be considered without ICT, in Turkey as all across the world. Based on this vision, thanks to some developments, starting from 1960's, in public and private sectors, universities, the Ministry of National Education and TUBITAK (Scientific and Technological Research Council of Turkey), it has been targeted to create a computer literate society (Keser, 2011). The dynamic process that started in 1984 with the use of computers in the processes of teaching and learning at schools (Demiraslan \& Usluel, 2008) has continued with serious initiatives for ICT integration, which includes the nation-wide, comprehensive FATIH Project, initiated in 2010, as an integration project based on advanced ICT. On the other hand, teacher education and effective technology integration in teaching processes are among challenging issues (Teo, 2015). It is observed that, in most initiatives of technology integration, the dimension of teacher education is not prioritized, and that the graduate pre-service teachers are trained in the job-related use of ICT through teacher education. For example, it was declared that, in the scope of FATIH Project, which is a national ICT integration initiative in Turkey, about 425 thousand teachers have been trained through face to face and distant in-service professional development activities. Some evaluations on Turkish educational system suggest that the contents of teacher education programmes are not adequate in terms of providing teachers with information about how to integrate technology to education (TEDMEM, 2015). It is also an arguable subject whether the ICTrelated vocational trainings provided for teachers who currently serve are effective and efficient, despite all time and resources reserved for them. In this regard, Usluel, Kuskaya, Mumcu and Demiraslan (2007) state that, although teachers are positive about the use of ICT in classes, they see the inadequate vocational trainings as an obstacle, and thus that vocational trainings should be questioned. Usun (2009) stressed, on the basis of previous experiences, problems are faced in the course of the application of teacher education programs about how to use new technologies in teacher education. This brings about the circular problem that since pre-service teachers are not trained adequately in the pre-service period in teaching-related use of ICT, they have to acquire the relevant information, skills and experience through their education.

As it is said by Baran et al. (2013), teacher training programs need a systematic set of strategies and practices to train teachers who can effectively use ICTs in their classroom. On the other hand, it is fair to say that the ICT-based courses offered at faculty of educations in Turkey, which are dedicated 
to teacher education, are not sufficient to enable pre-service teachers to acquire the relevant skills. Similarly, various studies put forward that pre-service teachers do not feel and consider themselves as who can use ICT in their class and they do not use ICT in innovative teaching strategies (Bardakci, 2013; Tondeur et al., 2017). However, Goktas, Yildirim and Yildirim (2009) emphasize the importance of the ICT integration to teacher education for the ICT integration to K-12 schools. Among thousands of pre-service teachers who graduate from faculty of educations in Turkey every year, a considerable number of teachers participate in the system who can easily use ICT for personal purposes but do not know how to integrate it to the teaching and learning processes. It is stated that although new-generation teachers may be skillful in personal use of technology, they are still in need of being trained and supported about education-related use of ICT (Russell, Bebell, O'Dwyer, \& O'Connor, 2003). Similarly, Doering, Hughes and Huffman (2003) state, based on various studies, that pre-service teachers are not prepared adequately about educational technologies. Koehler and Mishra (2009) further state that teachers have insufficient experience about the use of digital technologies in educational processes because of social and contextual factors that complicate the relationship of teaching and technology and that do not support the initiatives of technology integration.

Although many action plans have been developed for effective ICT integration in teacher education, still there are obstacles in practical dimension (Goktas, Yildirim \& Yildirim, 2009). On the other hand, The guidance course of Information Technologies continues to be effective through face-to-face and distance learning, which is still underway by Ministry Of National Education. It is stated that understanding the factors affecting teachers both pre-service and in-service will facilitate better applications in resource planning, curriculum development, and provision of infrastructure (Teo, 2015). The root of the problem may be naturally sought in the data about the use of ICT and which show the degrees of achievement on the targets concerning the use of ICT in education. Nevertheless, many studies have already showed that in case of low level of such variables as users' readiness, attitudes, convictions, and perception of benefit and ease-of-use, they abstain from use of ICT for job-related purposes (Birch \& Irvine 2009; Goktas, Yildirim \& Yildirim, 2009; Hammond, Reynolds \& Ingram, 2011; Hermans, Tondeur, Van Braak, \& Valcke, 2008; Kim et al., 2013; Russell, Bebell, O'Dwyer, \& O'Connor, 2003; Sahin, 2012; Teo, 2009; Teo, 2012). Abbitt (2011) states that pre-service teachers' convictions about the use of knowledge acquired in class context may provide a measure that would help evaluate the technology integration in teacher education. Therefore, this study aims to expose the education and experience that pre-service teachers acquire in the course of their study at schools of education in regard to the use of ICT in education. It is considered that the findings of the present study may help the stakeholders of the subject for a more realistic planning and application, create awareness for effective initiative of ICT integration, and draw attention to the importance of an understanding that is pedagogically-based and focused on teacher education.

\section{The Aim of the Study}

The aim of the study is to expose the education and experience that pre-service teachers acquire in the course of their study at schools of education in regard to the use of ICT in education. Within the context of this aim, the answers were sought to the following questions. 
1. How is the perception of pre-service teachers about education and support ICT integration throughout their education?

2. Does the perception of education and support of pre-service teachers about ICT integration throughout their educations how a significant difference according to the gender variable?

3. According to the education faculties where they study, how is the pre-service teachers' perception of education and support regarding ICT integration throughout their education?

\section{Sampling}

\section{Method}

The sampling group of the study is comprised of totally 832 pre-service teachers who were senior students, in 2016-2017 academic year, attending teacher education programs at the schools of education associated to 4 different state universities in Turkey. 609 (73\%) of the pre-service teachers are female while $223(27 \%)$ are male. The distributions of pre-service teachers according to the programs they have studied can be listed as 67 (\%8) Turkish Education, 67 (\%8) Social Studies Education, 189 (\%23) Primary School Education, 200 (\%24) Preschool Education, 198 (24) Special Education, 70 (\%8) Foreign Language Education, 18 (\%2) Mathematics Education and 23 (\%3) Guidance and Psychological Counselling. To avoid misinterpretation of the findings, the pre-service teachers who attend the Computer Education and Instructional Technology (CEIT) programs whose curriculum are mostly based on ICT were excluded from the sampling. The faculty of educations taking place in the sampling of this study are in the top-20 list, out of the 96 Turkish schools of education, according to the 2015 data of URAP (University Ranking by Academic Performance http://tr.urapcenter.org), which ranks universities of Turkey and around the world. The schools of educations taking place in the sampling of this study are categorized here, according to their academic performance scores on national and international scales, from the higher to the lower, as "faculty of education - 1", "faculty of education - 2", "faculty of education - 3", and "faculty of education -4 ". The data about the research sampling are presented in Figure 1.

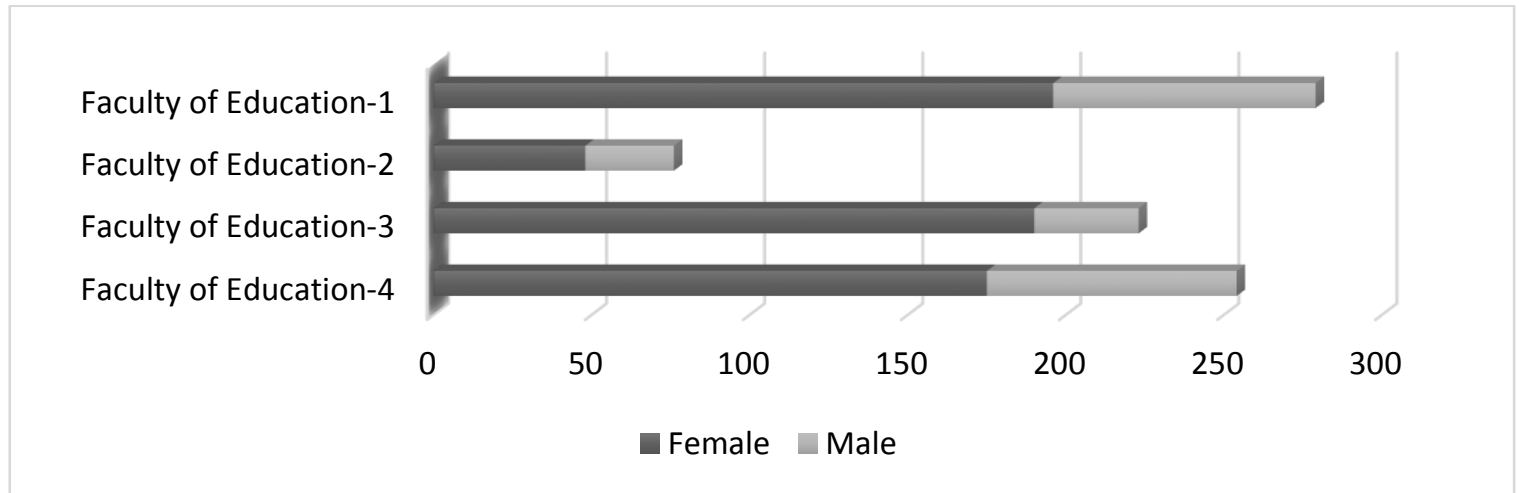

Figure 1. The Listing of the Schools of Education and the Distribution of the Sampling by Gender 


\section{Data Collection Tools}

The research data were collected through a form containing questions used to obtain independent variables and through the scale developed by Tondeur, van Braak, Siddiq and Scherer (2016) on the basis of SQD (Synthesis of Qualitative Evidence) model in order to determine pre-service teachers' perceptions of the levels of their experience of the education and support necessary for them to integrate technology to class activities. The SQD Model is composed of 12 key themes that contain teacher education and institutional factors in the scope of the use of technology and its integration in teacher education in general.

The scale developed in the model was created in the frame of the 6 key themes of the model which are related to teacher education. The scale is one-dimensional and composed of totally 22 items with the following themes: "Role model - Using teacher educators as role models" ( 4 items - Sample item: "I saw many examples of ICT use in an educational setting"), "Reflection - Reflecting on attitudes about the role of technology in education" ( 4 items - Sample item: "I was given the chance to reflect on the role of ICT in education"), "Instructional design - Learning technology by design" (4 items - Sample item: "I received sufficient help in designing lessons that integrated ICT"), "Collaboration - Collaborating with peers" (4 items - Sample item: "Students helped each other to use ICT in an educational context"), "Authentic experiences - Scaffolding authentic technology experiences" ( 3 items - Sample item: "Students were encouraged when they attempted to use ICT in an educational setting") and "Feedback - Moving from traditional assessment to continuous feedback" (3 items - Sample item: "My competences in using ICT in the classroom were regularly evaluated"). There is no negative item on the scale.

Cronbach alpha coefficient of the scale is $\alpha=0.95$. The SQD scale is of 6 point Likert structure between "totally disagree" and "totally agree." The highest score on the scale is 22 and the lowest score is 132. A high score on the scale indicates a more positive perception of pre-service teachers' related with levels of their experience of the education and support necessary for them to integrate technology to class activities.

To use the scale in the scope of the present study, the responsible author's permission was obtained first. Then the items of the scale, which originally in English, were translated to Turkish by a group of academics who are proficient in both languages and work in the field of Educational Technology. Prepared for the application, the scale was applied-in order to determine construct validity and for confirmatory factor analysis - to 324 senior students, with 222 (68\%) female and 102 (32\%) male, who attend schools of education in 3 different state universities in Turkey which are outside the sampling group of the present study.

The path coefficients related to the items, the value of the multiple correlation square $\left(R^{2}\right)$ that determine the strength of the relation between each item and hidden variable, and the $t$ value that indicates the significance of the relation were analysed and these values were found significant $(p<0.05)$. Fit indices are used to assess whether the observed data fit well to the one-dimensional model. The data-model fit indices calculated for the scale of 22 items in this study are shown in the Table 1. 
Table 1. Goodness of Fit Indices for Factorial Structure of the Scale

\begin{tabular}{|c|c|c|c|}
\hline Goodness of Fit Index & Acceptable & mit & Value \\
\hline $\mathrm{X}^{2} / \mathrm{sd}$ & $<5$ Moderate level & $<3$ Good fit & $306.74 / 209=1.46$ \\
\hline GFI & $>0.90$ & & 0.68 \\
\hline $\mathrm{CFI}$ & $>0.90$ & & 0.97 \\
\hline $\mathrm{NFI}$ & $>0.90$ & & 0.93 \\
\hline NNFI & $>0.90$ & & 0.97 \\
\hline RFI & $>0.85$ & & 0.93 \\
\hline S-RMR & $<0.08$ & & 0.072 \\
\hline RMSEA & $<0.08$ & & 0.074 \\
\hline
\end{tabular}

According to the Table 1, the ratio of resemblance chi-square was determined as $X^{2}(209)=306,74$; the ratio of $\mathrm{X} 2 / \mathrm{sd}$ as 1,46 ; root mean square error approximation as (RMSEA) $=0.074$; the standardized root mean square residual as $(\mathrm{S}-\mathrm{RMR})=0.072$; the comparative fit index as $(\mathrm{CFI})=0.97$; the goodness of fit index as $(\mathrm{GFI})=0.68$; the normed fit index as $(\mathrm{NFI})=0.93$; and the relative fit index as $(\mathrm{RFI})=0.93$. The confirmatory factor analysis indicated that the one-factorial structure of the scale is acceptable. The path diagram for the scale items is shown in the Figure 2.

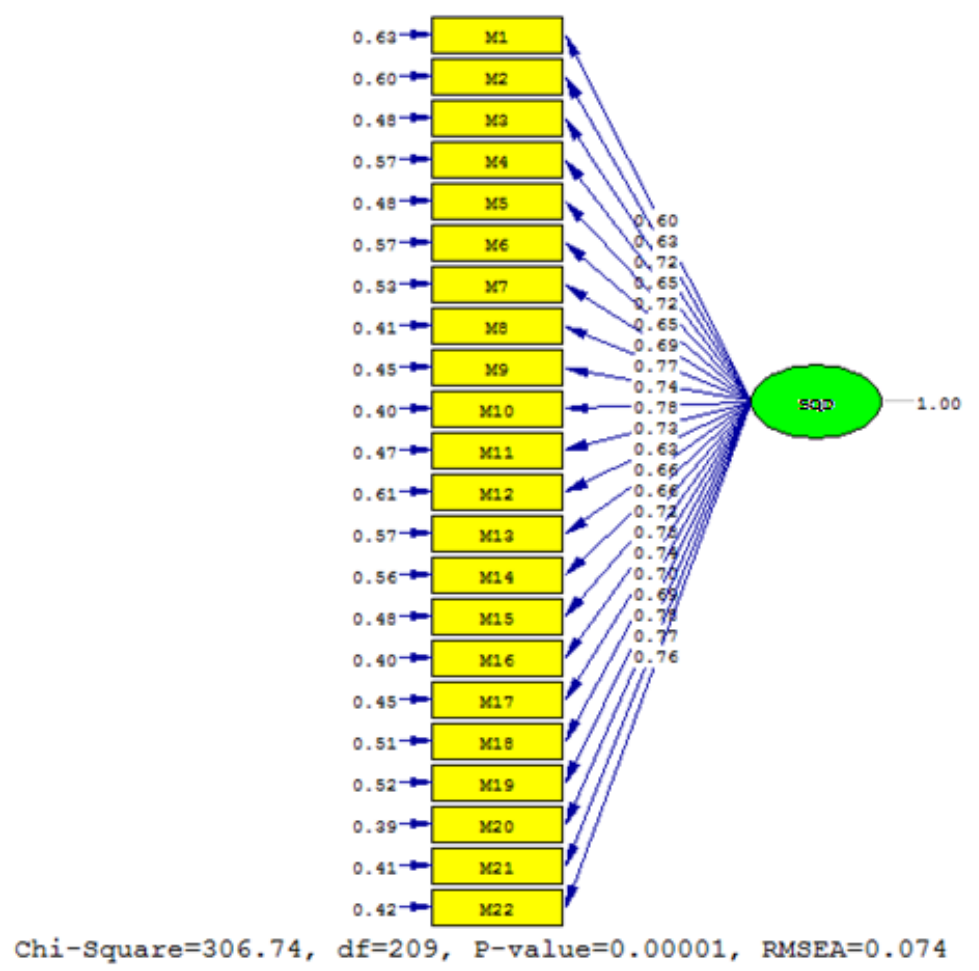

Figure 2. SQD-scale CFA Path Diagram

\section{Data Analysis}

In the analysis of the research data, whether the data demonstrate normal distribution was examined first. As the kurtosis and skewness values of the data on the basis of the scale items were 
between \pm 1.5 and showed normal distribution, the research data were analysed by using descriptive statistics and such parametric tests as t-test and one-way ANOVA test.

\section{Findings}

At first, on the basis of the scale themes and of the data of the general context of the scale, preservice teachers' perceptions of support and education in regard to the ICT integration. The findings of this analysis are shown in the Table 2.

Table 2. Pre-service Teachers' Perceptions of Support and Education about Integration during Their Study

\begin{tabular}{|c|c|c|c|c|c|}
\hline & $\mathbf{n}$ & $\begin{array}{l}\text { Number of items } \\
\text { (k) }\end{array}$ & $\overline{\boldsymbol{X}}$ & $x / k$ & ss \\
\hline Role model & 832 & 4 & 13.76 & 3.44 & 4.27 \\
\hline Reflection & 832 & 4 & 11.56 & 2.89 & 4.41 \\
\hline Instructional design & 832 & 4 & 11.82 & 2.95 & 4.39 \\
\hline Collaboration & 832 & 4 & 12.05 & 3.01 & 4.34 \\
\hline Authentic experiences & 832 & 3 & 8.73 & 2.91 & 3.45 \\
\hline Feedback & 832 & 3 & 8.05 & 2.68 & 3.50 \\
\hline SQD Score & 832 & 22 & 66.03 & 3.00 & 20.71 \\
\hline
\end{tabular}

It can be stated, according to the findings shown in Table 2, that pre-service teachers' perceptions of the level of receiving support and education during their study about ICT integration is below the medium level $\left(X^{-}=3.00\right)$. According to the findings, the average score of the answers for the items in the scope of the theme "Using teacher educators as role models" is higher compared to the other themes, while the lowest average score is of the items of the theme "Providing continuous feedback."

Whether pre-service teachers' perceptions of the level of receiving support and education during their study about ICT integration vary according to gender variables was also examined. The relevant findings are shown in the Table 3.

Table 3. Perception of Education and Support about Integration According to Gender

\begin{tabular}{clcccccc}
\hline Variable & Group & $\mathbf{n}$ & $\overline{\boldsymbol{X}}$ & $\mathbf{s d}$ & $\mathbf{t}$ & $\mathbf{d f}$ & $\mathbf{p}<$ \\
\hline SQD & Female & 609 & 64.86 & 20.21 & 2.69 & 830 & .007 \\
& Male & 223 & 69.21 & 21.74 & & & \\
\hline
\end{tabular}

$\mathrm{p}<.05$

The findings shown in the Table 3 indicate that pre-service teachers' perceptions of the level of receiving support and education during their study about ICT integration vary significantly according to gender variables $(\mathrm{t}(830)=2.69, \mathrm{p}<.007)$. It is observed that, on the basis of SQD variable, the average scores of male pre-service teachers are significantly higher than those of female ones. 
Another aspect of examination is pre-service teachers' opinions of receiving adequate support and education during their study about ICT integration, on the basis of the schools of education in the scope of the study. The relevant findings are shown in the Table 4.

Table 4. Perception of Education and Support about Integration According to Schools of Education

\begin{tabular}{lccc}
\hline & $\mathbf{n}$ & $\overline{\boldsymbol{X}}$ & sd \\
\hline faculty of education-1 & 279 & 68.31 & 22.29 \\
faculty of education-2 & 76 & 66.30 & 22.60 \\
faculty of education-3 & 223 & 66.23 & 18.08 \\
faculty of education-4 & 254 & 63.22 & 20.26 \\
\hline
\end{tabular}

According to the findings shown in the Table 4, the average scores about pre-service teachers' opinions of receiving adequate support and education during their study about ICT integration are, in order: faculty of education-1 $(\bar{X}=68.31)$, faculty of education-2 ( $\bar{X}=66.30)$, faculty of education-3 ( $\bar{X}=66.23)$, and faculty of education-4 $(\bar{X}=63.22)$. In addition to these average scores, an analysis was conducted to figure out whether there is any difference in the variable that is researched among the universities of the sampling, and the relevant findings are shown in the Table 5.

Table 5. Comparison of Universities on the Basis of Perception of Education and Support about Integration

\begin{tabular}{llcccccc}
\hline Variable & Source of variance & SS & df & KO & F & P & Source of difference \\
\hline SQD & Inter-groups & 3476.67 & 3 & 1158.89 & 2.71 & .044 & faculty of education-1 \\
& Intra-groups & 352995.45 & 828 & 426.32 & & & faculty of education-4 \\
\hline
\end{tabular}

$p<.05$

According to the findings shown in the Table 5, pre-service teachers' perceptions of receiving adequate support and education during their study about ICT integration demonstrate significant difference according to the schools of study $(F(3,828)=2.71, p<.05)$. According to the findings of the Scheffe multiple comparison test applied to determine the source of the difference, the difference results from the pre-service teachers attending the faculty of education- 1 and the faculty of education-4. Accordingly, it can be stated that the average scores about the levels of receiving necessary support and education about ICT integration during study on the part of the pre-service teachers attending the faculty of education $-1(\bar{X}=68.31)$ are significantly higher than those of the pre-service teachers attending the faculty of education- $4(\bar{X}=63.22)$.

\section{Discussion and Conclusion}

This study aims to expose the education and experience that pre-service teachers acquire in the course of their study at schools of education in regard to the use of ICT. The findings show that this acquisition is at medium level and even, for some themes, below it. In other words, pre-service teachers state that they do not receive adequate education and support during their study at faculty of education in the ICT-related subjects of using teacher educators as role models, reflecting on 
attitudes about the role of technology in education, learning technology by design, collaborating with peers, scaffolding authentic technology experiences, and providing continuous feedback. Each theme has a relation with another and has a particular significance. However, perhaps the most remarkable point is that while the concept of role model and its importance for pre-service teachers in many studies (Demirli, 2013; Goktas, Yildirim \& Yildirim, 2009; Martinovic \& Zhang, 2012; Tezci, 2011a; Tondeur et al., 2016), teacher educators are not adequately perceived as role models by preservice teachers in the subject of ICT-aided successful class applications. Furthermore, as it is expressed in some similar research, reflection and modelling are the most commonly used strategies in preservice teacher education programs (Baran et al., 2013). It is a necessity for the success of teacher education to be role model for pre-service teachers not only about ICT-aided classes but also in every stage of teaching and learning processes. Although pre-service teachers may acquire theoretical knowledge to some extent about use of ICT in class context, if teacher educators do not support their classes with successful ICT applications, it would be difficult for pre-service teachers to put their theoretical knowledge in practice and turn it into a skill. There may be various reasons of this situation. For example, it can be considered that teacher educators do not have adequate competence for being role model for pre-service teachers by blending their knowledge about technology, pedagogy, and field, as they participate in the process of teacher education by mostly passing through a traditional process of teaching. Usluel and Uslu (2016) report that teaching personnel state that they use ICT in the process of teaching and that they are in criticism about the way of this use. Besides, class sizes over capacity (Mutlu \& Erdem, 2013) and relative increase in teacher educators' work load (Kurt et al., 2013) may be considered among the possible reasons for the fact that the expectations of pre-service teachers in various subjects including being role model about in-class use of ICT are not met adequately. All possible reasons make us consider that, as Baran and Canbazoglu (2015) argue, pedagogic convictions and various contextual factors like institutional structure have negative impact on ICT applications.

Another important finding of the study is the difference between female and male pre-service teachers in regard to the use of ICT during the course of teacher education. Beside the statistical difference, it is remarkable that the average scores of both groups are far below the desired level, in terms that ICT applications in education are not sufficient for schools of education where majority of students are comprised of women. Many studies in the field literature suggest different findings in regard to the relation of ICT to the gender variable. In some studies, there found no difference, based on gender variable, between the use of ICT on the part of female and male pre-service teachers (Hammond, Reynolds \& Ingram, 2011; Teo, Chai, Hung, \& Lee, 2008), whereas in some others, the difference based on gender variable is usually for men, on the basis of acceptance, attitude, self-efficacy, and skills (Demirli, 2013; Siddiq, Scherer \& Tondeur, 2016; Teo, 2014; Tezci, 2011a). In this study, the male pre-service teachers' perceptions and opinions of receiving adequate support and education during their study about use of ICT are stated more highly compared to the female ones, and this finding is compatible with similar studies that take up the indicators about the use of ICT in teacher education (Akbulut, 2011; Tezci, 2011b). A possible reason of this situation may be the variables that affect female pre-service teachers' knowledge, skills and perspectives in regard to the use of ICT.

The last variable handled in this study is to examine the conditions of universities on the basis of the faculty of educations which pre-service teachers attend. According to the 2016-2017 academic year statistics of the Higher Education Council (https://istatistik.yok.gov.tr), there are totally 96 schools 
of education or educational sciences associated with state and private universities in Turkey. These schools have initiatives and applications with different levels and dimensions in regard to technology integration in teacher education. On the other hand, as stated by Goktas, Yildirim and Yildirim (2008), the schools of education do not have adequately proper technological plan, teacher education and institutional structure to benefit from ICT efficiently. The findings of this study indicate that pre-service teachers are not provided with adequate level of support and education about the use of ICT at the schools of education in the scope of the sampling. This can be explained with the shortcomings in the information accumulation and technological infrastructure about ICT integration on the part of the schools of education in question, and it can also be suggested that in schools deprived of comprehensive technologic plan and vision, pre-service teachers are not provided with necessary education and experience (Brun \& Hinostroza, 2014). The faculty of education-1 and the faculty of education- 4 , which are the subject of study in this research, are among the first 20 schools in Turkey in terms of academic performance. The place of the academic performance of the former in the national ranking is for above that of the latter. At the same time, the average of the perception of received education and support about ICT on the part of the students of the former school is higher compared to the other. The difference can be considered to result from the opportunities and shortcomings in regard to technical infrastructure and institutional support, as well as the different levels of communicating the information accumulation about the use of ICT to pre-service teachers.

Consequently, it is not easy to to assert that the system of teacher education in Turkey has successful ICT integration and that pre-service teachers who attend teacher education programmes acquire adequate education and experience in regard to the use of ICT. Some steps might have been taken so far, which might not be at desired level though, but the importance of educational processes for the socio-cultural structure and future of the society, the fact that the outcomes of education manifest themselves over the long term make it unacceptable to ignore the experiences and results of the previous applications ICT integration. Such would be ineffective initiatives based on a trial and error learning. As this study has emphasized, technology integration in education should be started at schools of education to train adequate number of teachers and pre-service teachers who are able to use ICT sufficiently, and then should be spread to all schools with nation-wide projects. In other words, the starting point of the technology integration in education should be teacher education. This will also bring about the efficient use of the labour force, technical infrastructure and financial resources and will help realize effective implementations. Nevertheless, it is observed that pre-service teachers are not fully ready for the process of ICT integration in education. Therefore, the following points can be suggested in the context of the findings of this study and the relevant literature:

- It is suggested that schools of education introduce their own visions about ICT integration and develop their plans. It is a matter of discussion whether a centralized, common approach will bring positive outcomes. For each faculty of education has its own culture, a distinct profile of students and teaching personnel, and its own financial and technical infrastructure. Nonetheless, some measures may naturally be posited which would embody the expected and desired level nation-wide. Therefore, instead of a centralized planning, it would be more effective that each school evaluates its own human and nonhuman resources and develops a plan to attain national qualifications. It would be more 
efficient for the sake of coordination to make this plan with the participation of teacher educators, teachers and pre-service teachers.

- Professional development activities, based on such approaches as education the trainers and lifelong learning, can be organized at the level of higher education in order to enable the teaching personnel who serve at schools of education to increase their knowledge and skills in regard to the use of ICT for personal and educational purposes. An important point here is that the teaching personnel in question are, besides being teacher educators, academics. Thus, to improve their willingness and motivation for participation in such activities, participants may be given extra points to be used in the system of academic promotion.

- The facts that teaching personnel working at schools of education have usually and relatively intense work/course load and the teacher education programs in Turkey have high admission quotas may naturally be seen as problematic for teaching personnel. Thus it would be beneficial to lower the course load of the teaching personnel to create for them time convenient to acquire knowledge and skills about ICT during the teaching activities. In parallel to this, it would also be useful for the sake of efficient ICT applications to regulate the admission quotas of the schools of education and lower them to plausible numbers that would facilitate more efficient class settings.

- The fact that the ICT-related knowledge and experience that pre-service teachers acquire during their study are limited to undergrad courses may result in the relevant development to be slow and ineffective. Thus the process may be expedited with the help of frequently-organized ICT-related activities like seminars, workshops, courses, etc. at schools of education.

- It would be useful to create facilities enabling pre-service teachers to put in practice, after graduation, what they acquire during their study about ICT-related knowledge and skills, at their schools of service. An important point here is that the course called School Experience and Teaching Practice, which takes place only in the last grade in most of the undergrad programs, may be insufficient to this end. Besides, teaching-related ICT applications at different levels of educational system other than the higher education have problems in their respective contexts. Thus it is inevitable, for the sake of effective applications that schools of education and the schools affiliated to the Ministry of National Education work in cooperation regarding ICT applications. Moreover, in addition to the existing condition of the courses of School Experience and Teaching Practice, it can also be held in periods before the last grade with the help of increase in the number of the course in question, which would give pre-service teachers more opportunities to make observations and have experiences.

Finally, it should be noted that the present study has limitations in its scope. First, the research data were collected with a scale based on the teaching-related variables of the model that examines technology integration in education. Thus both the findings and the researcher's approach took place in this context. Likewise, the findings are limited to the perceptions and opinions of the preservice teachers who study at the schools of education from which the research data were collected. 
Although these universities have high rankings among the schools of education in Turkey and the sampling size is large, it would be proper to include more schools of education in the sampling to make generalizations in the subject. It should also be taken into account that the findings and conclusions are only based on the opinions of the participant pre-service teachers. For a more precise generalization in the subject, it would be useful to appeal to the points of view of the different stakeholders like teaching personnel and deans serving at schools of education, teachers and school principals.

\section{References}

Abbitt, J. T. (2011). An investigation of the relationship between self-efficacy beliefs about technology integration and technological pedagogical content knowledge (TPACK) among preservice teachers. Journal of Digital Learning in Teacher Education, 27(4), 134-143.

Akbulut, Y., Odabasi, H.F., \& Kuzu, A. (2011). Perceptions of preservice teachers regarding the integration of information and communication technologies in Turkish education faculties. The Turkish Online Journal of Educational Technology (TOJET), 10(3), 175-184.

Bardakci, S. (2013). ICT integration in education: An investigation of different purposes, policies, practices, effects and criticisms (Unpublished PhD thesis). Ankara University Educational Sciences Institute, Ankara, Turkey.

Baran, E. \& Canbazoglu Bilici, S. (2015). A review of the research on technological pedagogical content knowledge: The case of Turkey. Hacettepe University Journal of Education, 30(1), 15-32.

Baran, E., Canbazoglu Bilici, S., Albayrak Sari, A., \& Tondeur, J. (2017), Investigating the impact of teacher education strategies on preservice teachers' TPACK. British Journal of Educational Technology. doi:10.1111/bjet.12565

Birch, A. \& Irvine, V. (2009). Preservice teachers' acceptance of ICT integration in the classroom: applying the UTAUT model. Educational Media International, 46(4), 295-315.

Brun, M. \& Hinostroza, J. E. (2014). Learning to become a teacher in the 21st century: ICT integration in initial teacher education in Chile. Educational Technology \& Society, 17(3), 222-238.

Demiraslan, Y. \& Usluel, Y. K. (2008). ICT integration processes in Turkish schools: Using activity theory to study issues and contradictions. Australasian Journal of Educational Technology, $24(4), 458-474$.

Demirli C. (2013). ICT usage of pre-service teachers: Cultural comparison for Turkey and Bosnia and Herzegovina. Educational Sciences: Theory and Practice, 13(2). 1095-1105.

Doering, A., Hughes, J., \& Huffman, D. (2003). Preservice teachers: Are we thinking with technology? Journal of Computing in Teacher Education, 35(3), 342-361.

Goktas, Y., Yildirim, Z., \& Yildirim, S. (2008). Status of ICT in schools of teacher education: Deans' Views. Education and Science, 33(149), 30-50. 
Goktas, Y., Yildirim, S., \& Yildirim, Z. (2009). Main barriers and possible enablers of ICTs integration into pre-service teacher education programs. Educational Technology \& Society, 12(1), 193204.

Hammond, M., Reynolds, L., \& Ingram, J. (2011). How and why do student teachers use ICT?, Journal of Computer Assisted Learning, 27(3), 191-203.

Hermans, R., Tondeur, J. van Braak, J., \& Valcke, M. (2008). The impact of primary school teachers' educational beliefs on the classroom use of computers. Computers\&Education, 51, 14991509.

Jamieson-Proctor, R., Finger, G., \& Albion, P. (2010). Auditing the TK and TPACK confidence of preservice teachers:Are they ready for the profession? Australian Educational Computing, 25(1),8-17.

Kabakci-Yurdakul, I. (2011). Examining Technopedagogical Knowledge Competencies of Preservice Teachers Based on ICT Usage. Hacettepe University Journal of Education, 40, 397-408.

Keser, H. (2011). The first step for computer education in Turkey: The expertise commission report of computer education in secondary school. Educational Technology Theory and Practice. 2(2),83-94.

Kim, C., Kim, M., Lee, C. J., Spector, M., \& DeMeester, K. (2013). Teacher beliefs and technology integration. Teaching and Teacher Education, 29, 76-85.

Koehler, M. J. \& Mishra, P. (2009). What is technological pedagogical content knowledge? Contemporary Issues in Technology and Teacher Education, 9(1), 60-70.

Kurt, A. A., Kuzu, A., Dursun, O. O.., Gullupinar, F., \& Gultekin, M. (2013). Evaluation of the pilot application process of FATIH Project: Teachers' views. Journal of Instructional Technologies and Teacher Education (JITTE), 1(2), 1-23.

Martinovic, D. \& Zhang, Z. (2012). Situating ICT in the teacher education program: Overcoming challenges, fulfilling expectations. Teaching and Teacher Education, 28(3), 461-469.

Mutlu, P. \& Erdem, M. (2013). The relationship between it teachers' awareness of Turkey's ICT vision and their teaching activities. Elementary Education Online, 12(4), 981-999.

OECD (2015). Students, computers and learning: Making the connection - PISA, Paris: OECD. Retrieved on 19 June 2017 from http://dx.doi.org/10.1787/9789264239555-en.

Russell, M., Bebell, D., O'Dwyer, L., \& O'Connor, K. (2003). Examining teacher technology use: Implications for preservice and inservice teacher preparation. Journal of Teacher Education, 54, 279-310.

Sahin, S. (2012). Pre-service teachers' perspectives of the diffusion of information and communications technologies (ICTs) and the effect of case-based discussions (CBDs). Computers \& Education, 59, 1089-1098.

Sahlberg, P. (2010). The secret to Finland's success: Educating teachers. Stanford Center for Opportunity Policy in Education-Research brief. Retrieved on 19 June 2017 from https://edpolicy.stanford.edu/publications/pubs/290. 
Siddiq, F., Scherer, R., \& Tondeur, J. (2016). Teachers' emphasis on developing students' digital information and communication skills (TEDDICS): A new construct in 21st century education. Computers \& Education, 92-93, 1-14.

Sleegers P., van den Berg R., \& Geijsel F. (2000). Building new innovative schools: The need for new approaches. Essay review. Teaching and Teacher Education, 16, 801-808.

TEDMEM (2015). Gunah kecisi teknoloji mi? [Is technology scapegoat?]. Retrieved on 4 March 2017 from http://www.tedmem.org/mem-notlari/gunah-kecisi-teknoloji-mi

TEDMEM. (2015). 2015 Egitim degerlendirme raporu [2015 Education Evaluation Report]. Ankara: Türk Egitim Dernegi.

Teo, T. (2009). Modelling technology acceptance in education: A study of pre-service teachers. Computer\&Education, 52(2), 302-312.

Teo, T. (2012). Examining the intention to use technology among pre-service teachers: An integration of the Technology Acceptance Model (TAM) and Theory of Planned Behavior (TPB). Interactive Learning Environments, 20(1), 3-18.

Teo, T. (2014). Unpacking teachers' acceptance of technology: tests of measurement invariance and latent mean differences. Computers \& Education, 75, 127-135.

Teo, T. (2015). Comparing pre-service and in-service teachers' acceptance of technology: Assessment of measurement invariance and latent mean differences. Computers \& Education, 83, 22-31.

Teo, T., Chai, C. S., Hung, D., \& Lee, C. B. (2008). Beliefs about teaching and uses of technology among pre-service teachers. Asia Pacific Journal of Teacher Education, 36(2), 165-176.

Tezci, E. (2011a). Factors that influence pre-service teachers' ICT usage in education. European Journal of Teacher Education, 34(4), 483-499.

Tezci, E. (2011b). Turkish primary school teachers' perceptions of school culture regarding ICT integration. Educational Technology Research and Development, 59, 429-443

Tondeur, J., van Braak, J., Sang, G., Voogt, J., Fisser, P., \& Ottenbreit-Leftwich, A. (2012). Preparing pre-service teachers to integrate technology in education: A synthesis of qualitative evidence. Computers \& Education, 59, 134-144.

Tondeur, J., van Braak, J., Siddiq, F., \& Scherer, R. (2016). Time for a new approach to prepare future teachers for educational technology use: Its meaning and measurement. Computers \& Education, 94, 134-150.

Tondeur, J., Aesaert, K., van Braak, J., Pynoo, B., Freyman, N., \& Erstadt, O. (2017). Developing a validated instrument to measure pre-service teachers' ICT competencies: meeting the demands of the 21st-century. British Journal of Educational Technology, 48(2), 462-472.

Usluel, Y. K., Mumcu, F. K., \& Demiraslan Y. (2007). ICT in the learning-teaching process: Teachers' views on the Integration and obstacles. Hacettepe University Journal of Education, 32, 164 179. 
Usluel, Y.K. \& Uslu, N.A. (2016). Ogretmen adaylarinin yetistirilmesi surecinde ogretim uyeleri perspectifinden BIT entegrasyonu [ICT Integration from the perspective of instructors in the process of teacher training]. XVIII. Academic Informatics Conference (AB16). Adnan Menderes University, Aydin, Turkey.

Usun, S. (2009). Information and communication technologies (ICT) in teacher education (ITE) program in the world and Turkey. In H.Uzunboylu \& N.Cavus (Eds.), Procedings of new trends and issues in educational sciences (pp. 331-334). Nicosia, North Cyprus.

Correspondence: Cem Cuhadar, Associate Professor, Department of Computer Education and Instructional Technologies, Faculty of Education, Trakya University, Edirne, Turkey 